\title{
Outer cell wall structure and the secretion mechanism of colleters of Bathysa nicholsonii K. Schum. [Rubiaceae]
}

\author{
Emilio de Castro Miguel', Saulo Pireda², Claudia Franca Barros ${ }^{3}$, Umberto Zottich4, Valdirene Moreira Gomes ${ }^{5}$, \\ Flavio Costa Miguens ${ }^{2}$ and Maura Da Cunha ${ }^{2 *}$
}

Received: December 9, 2016

Accepted: January 31, 2017

\begin{abstract}
Secretory structures are formed by many types of plants and are present on numerous different organs. Among the many types of known secretory structures, colleters are predominant on plants of the Rubiaceae. One remarkable characteristic of secretory tissues is the export of exudates; however, the precise mechanism involved in this process is still unclear. To better understand the mechanisms of exudate externalization it is necessary to understand the ultrastructure and dynamics of the outer cell wall of the secretory structures during the secretory process, and so we investigated these aspects of the colleters of Bathysa nicholsonii. The outer cell wall (OCW) exhibits multiple layers: a basal polysaccharide rich layer; a cuticular membrane, which is subdivided into arborescent and reticulated layers; and a thin cuticle proper. The structural organization of the OCW is changed during secretion passage, which is mainly related to the development of a secretion accumulation site on the polysaccharide rich layer. Secretion dynamics is driven by the organization and disruption of the secretion accumulation site. The results show that the OCW of the colleters of $B$. nicholsonii is a dynamic structure with an active role in secretion externalization via constant structural reorganization directly related to secretion passage.
\end{abstract}

Keywords: colleters, outer cell wall, Rubiaceae, secretion accumulation site, secretion mechanism, secretory structures, secretory tissues

\section{Introduction}

Secretory structures and tissues occur on numerous different plant organs and are characterized by their distinct forms (Dickinson 2000). The classification of secretory structures is based mainly on morphology or exudate composition. However, this classification is questionable since secretory tissues, generally, experience transformations over a short period of time. In this manner, the structure, ultrastructure and biochemical composition of secretory cells can be modified quickly, making classification difficult because similar tissues may appear different because they were analyzed at different life cycle phases (Fahn 1979).

Colleters are secretory structures consisting of a parenchymatous middle axis surrounded by a layer of secretory palisade-like epidermal cells. These structures

\footnotetext{
${ }^{1}$ Departamento de Física, Central Analítica, Universidade Federal do Ceará, 60455-900, Fortaleza, CE, Brazil

${ }^{2}$ Laboratório de Biologia Celular e Tecidual, Universidade Estadual do Norte Fluminense Darcy Ribeiro, 28013-620, Campos dos Goytacazes, RJ, Brazil

${ }^{3}$ Laboratório de Botânica Estrutural, Instituto de Pesquisas Jardim Botânico do Rio de Janeiro, 22460-036, Rio de Janeiro, RJ, Brazil

${ }^{4}$ Centro de Ciências da Saúde, Universidade Federal de Roraima, 69300-000, Boa Vista, RR, Brazil

${ }^{5}$ Laboratório de Fisiologia e Bioquímica de Microrganismos, Universidade Estadual do Norte Fluminense Darcy Ribeiro, 28013-620, Campos dos Goytacazes, RJ, Brazil
}

* Corresponding author: maurauenf@gmail.com 
are present mainly on the adaxial surface of the stipule and occur in 60 angiosperm families (Thomas 1991; Da Cunha \& Vieira 1993). The function of colleters is still under debate, but it is believed that they protect the shoot apex and lateral buds by a physical or chemical mechanism (Thomas 1991).

Colleters have been the subject of many studies of different aspects of their anatomy and ultrastructure (Renobales et al. 2001; Klein et al. 2004; Miguel et al. 2006; 2009; 2010; Wilkinson 2007; Paiva 2009; Martins et al. 2010; 2012); histochemistry (Gonzalez \& Tarragó 2009; Vitarelli \& Santos 2009) and ontogenesis (Paiva \& Machado 2006). However, one of the most intriguing aspects of colleters is still poorly known: the structure of the cell wall.

The primary cell wall of plants has a fiberglass-like structure, with crystalline cellulose microfibrils that are embedded in a matrix of complex polysaccharides, which are divided into two classes: pectins, which are polysaccharides that are solubilized by aqueous buffers and dilute acidic solutions or calcium chelators; and hemicelluloses that require strong alkali for solubilization. The cellulose is synthesized by large membrane complexes which extrude microfibrils from the surface of the plasma membrane (Cosgrove 2005).

The hydrophilic layer of the cell wall is covered by a continuous extracellular membrane of soluble and polymerized lipids called the cuticle or cuticular membrane (Heredia 2003). The structure and composition of the cuticle varies widely among plants, organs and growth stages (Arpenter et al. 2007). Most authors restricted the term cuticle to the outermost, cellulose-free region (Fernández et al. 2016). The presence of cuticle is very ancient, having been recorded since the Devonian when plant diversification and morphological complexity experience a dramatic increase (Guo \& Wang 2016).

The cuticle is synthesized by the epidermis of fruits, leaves, primary stems and flower organs. It is composed of a polymer matrix called cutin, a polymer matrix called cutan, and intracuticular and epicuticular waxes (Pollard et al. 2008).

The outer cell wall is the frontier zone between the plant and the environment, and controls the entry and exit of substances (Pollard et al. 2008). This ubiquitous function makes the outer cell wall unique compared to inner cell walls. Under transmission electron microscopy, this structure can be seen to be divided into epicuticular wax and three distinct layers: the cuticle proper; the cuticular membrane which is divided into reticulated and arborescent layers; and the polysaccharide rich layer (Tenberge 1992). The composition of the cuticle influences its mechanical proprieties. Although most cuticles share a similar basic composition, differences in the percentage of each cuticle fraction or in the composition of a fraction have been found among species and organs (Dominguéz et al. 2011).

Cuticles of leaves need to be both permeable and impermeable. They protect internal leaf issues by providing a physical barrier against pathogens, herbivores, and the conductance of ultraviolet light and water (Riederer \& Schreiber 2001). However, in secretory structures, the secretory tissue must be specialized to transport substances to outside of the cell. This particularity makes the cell wall of secretory structures different from other regions of the plant, and distinct cell wall organization can be noted. Nevertheless, the general structures are, in the most part, similar to what was just described previously.

The transport of substances through the outer cell wall at secretory structures is still poorly understood. Most works that have referred to the passage of substances through the outer cell wall used transmission electron microscopy and only cite the presence or absence of a cuticle (Klein et al. 2004).

With regard to the actual secretion mechanism, it is possible that secretion is accumulated in periplasmic space between the cell wall and the plasma membrane (Ascensão \& Pais 1998; Paiva 2016). Another accumulation site noted is subcellular space formed by the dislocation of the cuticle; this space is referred to as the subcuticular space (Possobom \& Machado 2005). Other authors have suggested that in Cannabis glandular trichomes, secretion passage through outer cell wall is achieved by means of secretory cavities that act to release exudates (Mahlberg \& Kim 1992; Kim \& Mahlberg 1997; 2000).

Structures also considered to be secretory cavities were described for the colleters of Bathysa nicholsonii (Rubiaceae), however, the cuticle in this case was continuous (Miguel et al. 2006). Other colleters from species of Rubiaceae, such as species of Simira (Klein et al. 2004) and Psychotria nuda (Miguel et al. 2009), for example, were described without the cuticle rupturing during the secretory process.

Even with the speculation that the cell wall participates in the secretory process, more needs to be elucidated regarding the true behavior of the cell wall during the secretion of substances. Thus, the aim of this work was to describe the fine structure of the outer cell wall of colleters of Bathysa nicholsonii (Rubiaceae), focusing on understanding the mechanism of the passage of substances.

\section{Materials and methods}

\section{Plant material}

Shoot apexes of Bathysa nicholsonii K. Schum. were collected at Reserva Biológica de Tinguá, in the municipal district of Duque de Caxias, Rio de Janeiro State, Brazil $\left(22^{\circ} 28^{\prime} 22^{\circ} 39^{\prime} \mathrm{S}, 22^{\circ} 35^{\prime} 43^{\circ} 34^{\prime} \mathrm{W}\right)$. The area is located between 220 and 1,600 $\mathrm{m}$ above sea level, with an annual average temperature of approximately $21.6^{\circ} \mathrm{C}$ and pluviosity of 2,268 mm (Fundação SOS Mata Atlântica and Instituto Nacional de Pesquisas Espaciais 2002). Plants were found in vegetation recognized as Atlantic Forest. For observation 
under transmission electron microscopy, stipules containing secretory colleters were separated using tweezers and blades.

\section{Transmission electron microscopy}

For transmission electron microscopy, stipule fragments were fixed for two hours in a solution of $2.5 \%$ glutaraldehyde and $4.0 \%$ formaldehyde in $0.05 \mathrm{M}$ sodium cacodylate buffer, $\mathrm{pH}$ 7.2. Subsequently, the samples were rinsed in the same buffer and post-fixed for one hour at room temperature with $1.0 \%$ osmium tetroxide in $0.05 \mathrm{M}$ sodium cacodylate buffer, $\mathrm{pH}$ 7.2. The material was then embedded in epoxi resin (Epon $\left.{ }^{\circ}\right)$. Ultrathin sections $(60 \mathrm{~nm})$ were collected on copper grids (300 mesh) and stained with $1.0 \%$ alcoholic uranyl acetate followed by $5.0 \%$ aqueous lead citrate (Reynolds 1963). Sections were observed at $80 \mathrm{kV}$ using a transmission electron microscope (Zeiss TEM 900/JEOL JEM1400).

\section{Osmium/imidazole}

To enhance lipid contrast, samples were fixed for twelve hours in a solution of $2.5 \%$ glutaraldehyde and $4.0 \%$ formaldehyde in $0.05 \mathrm{M}$ imidazole buffer, $\mathrm{pH}$ 7.2. Subsequently, the samples were rinsed in the same buffer and post-fixed for seventy-two hours at room temperature with $1.0 \%$ osmium tetroxide in $0.05 \mathrm{M}$ imidazole buffer, $\mathrm{pH}$ 7.2. The material was then embedded in epoxi resin (Epon $\left.{ }^{\circ}\right)$. Ultrathin sections $(60 \mathrm{~nm}$ ) were collected on copper grids (300 mesh) and observed, without contrast, at $50 \mathrm{kV}$ using a transmission electron microscope (Zeiss TEM 900/JEOL JEM1400) (Angermuller \& Fahimi 1982)

\section{Potassium iodine}

To detect unsaturated substances of the outer cell wall, samples were fixed for two hours in a solution of $2.5 \%$ glutaraldehyde, $4.0 \%$ formaldehyde and $1 \%$ potassium iodine in water. Subsequently, the samples were rinsed in $1 \%$ potassium iodine in water (Locke \& Huie 1983). The material was then embedded in epoxi resin (Epon ${ }^{\circ}$ ), sectioned and collected on copper grids, as previously described. Sections were not contrasted and were observed at $80 \mathrm{kV}$ using a transmission electron microscope (ZEISS TEM 900/JEOL JEM1400).

\section{Results}

Careful observation of the cells of secretory colleters under transmission electron microscopy allowed the recognition of six different ultrastructural stages of the outer cell wall that are related to secretion passage on secretory colleters.

In the first stage, the outer cell wall possessed three ultrastructurally distinct layers: a basal polysaccharide rich layer; a cuticular membrane subdivided into arborescent and reticulated layers; and a thin cuticle proper (Fig. 1A).

In the second stage, the outer cell wall possessed a similar structure, except for the development of a secretion accumulation site (SAS) on the polysaccharide rich layer (Fig. 1B). Cytochemical tests confirmed that the lumen of the SAS is formed of lipids, as shown by the osmium/imidazole technique (Fig. 1C). The potassium iodine technique showed the SAS, as well as the arborescent layer of the cuticular membrane (Fig. 1D). Neither technique revealed a polysaccharide rich layer.

The third stage was characterized by an increase in size of the SAS. This structure exceeds the polysaccharide rich layer and the arborescent layer of the cuticular membrane (Fig. 2A). The osmium/imidazole technique stained the cuticular membrane and the SAS contents homogeneously, but not the polysaccharide rich layer (Fig. 2B).

In the fourth stage the SAS seamed to disorganize, making the polysaccharide rich layer thin and providing the appearance of projections (Fig. 2C). The potassium iodine technique evidenced a heterogeneous stain on the cuticular membrane, with it being strong on the arborescent layer and weak on reticulated layer (Fig. 2D). The osmium/ imidazole technique evidenced a homogenous stain on the cuticular membrane; there was no stain on polysaccharide rich layer (Fig. 2E).

In the fifth stage, the cell wall was characterized by a reorganization of cuticular membrane strata. The arborescent layer became dense, immediately above the polysaccharide rich layer, and the reticulated layer exhibited strongly-stained filaments (Fig. 3A). Potassium iodine showed structures similar to the previously stage (Fig. 3B). No SAS was observed.

The sixth stage was differentiated by a drastic reorganization and/or degradation of the layers of the cuticular membrane. Sometimes these layers were almost indistinguishable (Fig. 3C), or the arborescent layer was degraded (Fig. 3D).

Based on the micrographs obtained after careful observation, a dynamic model of secretion passage through the outer cell wall was developed. In this model, the cell wall is an active structure, changing in organization according to stage. This reorganization of the cell wall (Fig. 4) makes the passage of secretion possible.

\section{Discussion}

The outer cell wall is the border between the plant and the environment, and it can establish barriers that restrict the input and output of substances (Pollard et al. 2008). This control of the passage of substances is related to the fact that this structure has a hydrophilic region, a polysaccharide layer, a hydrophobic region, a cuticle membrane and a cuticle (Tenberge 1992). To understand how substances pass through the outer cell wall, many 

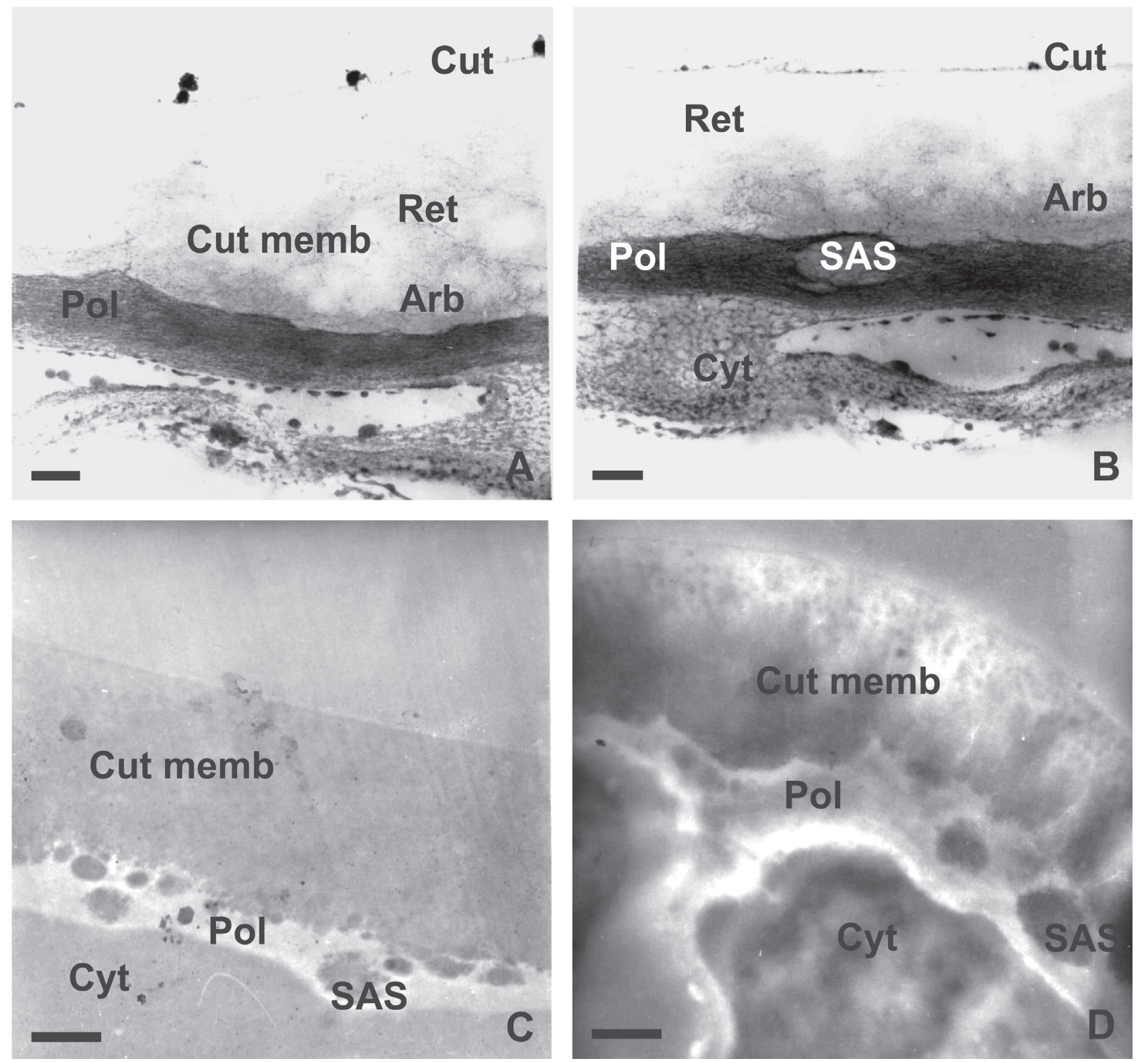

Figure 1. Transmission electron microscopy of the outer cell wall of the epidermis of colleters of Bathysa nicholsonii. A - First stage, outer cell wall with uranyl acetate/lead citrate contrast; B, C and D - Second stage, outer cell wall. B - Uranyl acetate/lead citrate contrast. Note secretion accumulation site (SAS) at polysaccharide layer. C - Potassium iodine stain. D - Osmium imidazole stain. Note homogeneous stain at secretion accumulation site (SAS) and lipid layer. Pol - outer cell wall polysaccharide layer; Cut memb cuticular membrane, subdivided into reticulated (Ret) and arborescent (Arb) layers; Cut - cuticle proper; Cyt - cytoplasm. Bars: A, B - $0.15 \mu \mathrm{m} ; C$ and D - $0.4 \mu \mathrm{m}$.

studies have investigated secretory structures, since they are specialized in the release of secretion to the external environment (Kim \& Mahlberg 2000; Veys et al. 2002; Paiva \& Machado 2006; Miguel et al. 2016). Sample preparation can modify cuticular structure. Guzmán et al. (2014) elucidated differences in the ultrastructure of the leaf cuticle in relation to the transmission electron microscopy procedures. On the other hand, Pinheiro et al. (2015) showed that colleter cuticles observed under environmental scanning electron microscopy was similar to processed samples. The influence of sample preparation on secretory cell ultrastructure is still poorly explored and deserves special attention.

The outer cell wall of secretory cells allows the passage of secretion into the extracellular environment; however, these processes are still poorly understood. Some models of the passage of secretion through the outer cell wall have been proposed. Miller (1985) revealed the presence of hydrophilic pores or channels with anticlinal orientation through the cell wall. Subsequently, Schönherr (2006) demonstrated that 


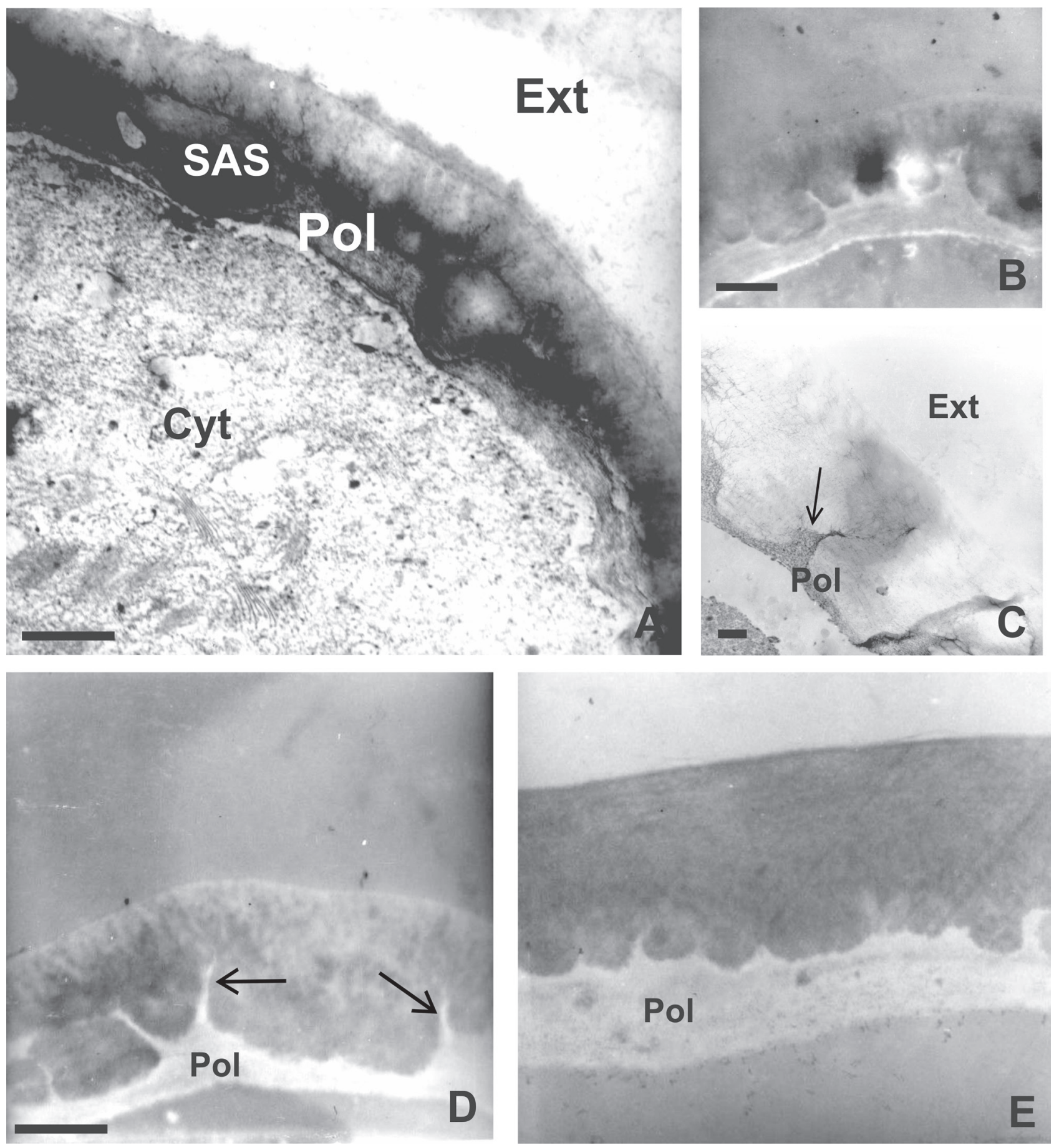

Figure 2. Transmission electron microscopy of the outer cell wall of the epidermis of colleters of Bathysa nicholsonii. A and B - Third stage, outer cell wall. A - Outer cell wall with a large secretion accumulation site (SAS) occupying most of the polysaccharide layer, and invading the cuticular membrane layer; uranyl acetate/lead citrate contrast. B - Osmium/imidazole stain. C, D and E - Forth stage, outer cell wall. C - Uranyl acetate/lead citrate contrast. Note the polysaccharide layer projections on the lipid layer. D - Potassium iodine stain. E - Osmium imidazole stain. Ext - extracellular extract; Cyt - cytoplasm; Pol-polysaccharide rich layer; Arrow - polysaccharide layer projections on cuticular membrane. Bars: A - $0.12 \mu \mathrm{m}$; B-E - $0.4 \mu \mathrm{m}$.

these channels measured approximately 0:45 to $1: 18 \mathrm{~nm}$ and formed hydrophilic pathways through the cuticular layer for the passage of hydrated ionic components. This secretion mechanism has been described for salt glands in Tamarix aphylla (Tamaricaceae) (Thomson et al. 1969), and in nectaries of Platanthera chlorantha (Orchidaceae) (Stpiczynska 2003). For the passage of the hydrophobic components through the outer wall, another mechanism that is not dependent on 

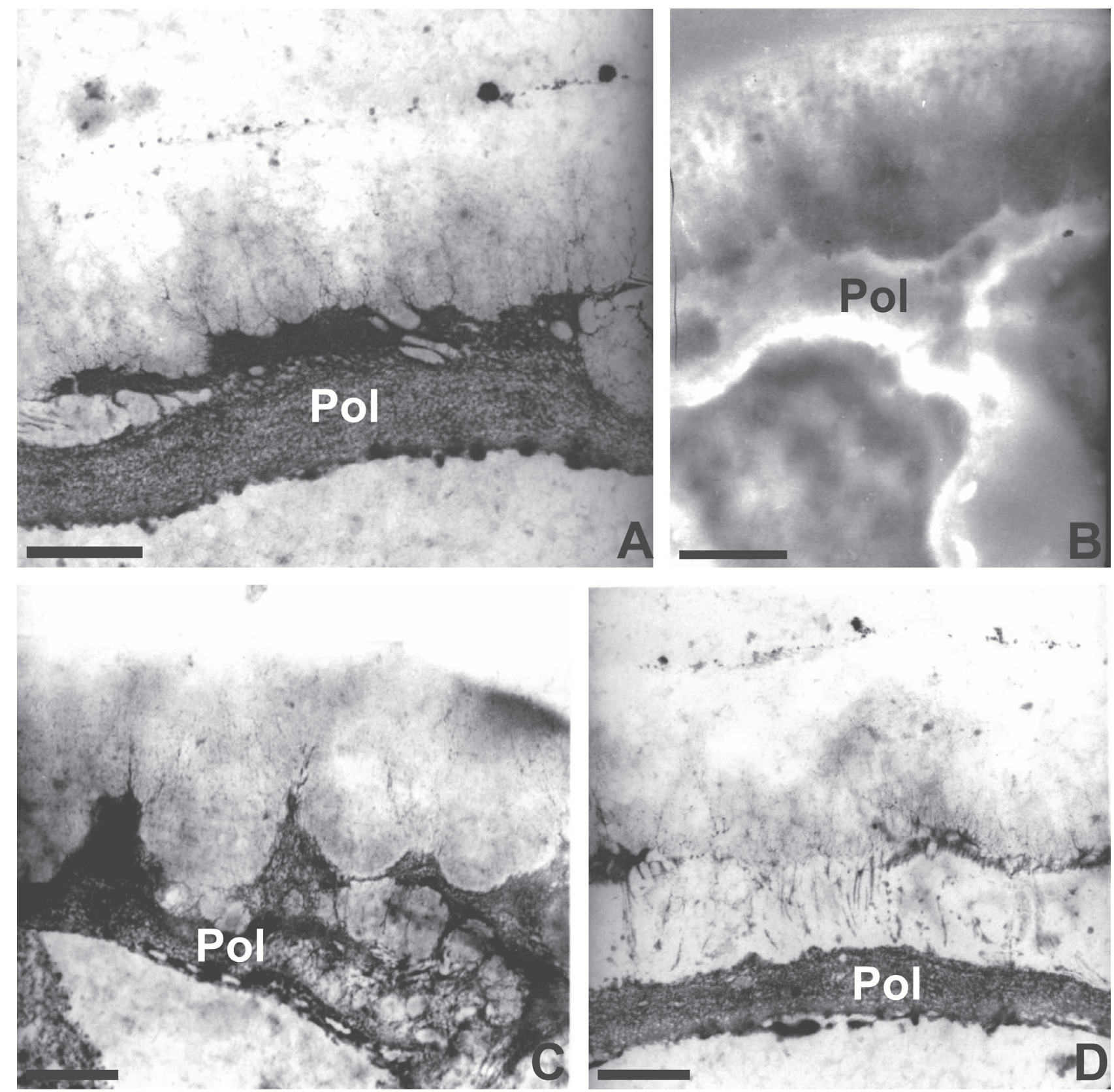

Figure 3. Transmission electron microscopy of the outer cell wall of the epidermis of colleters of Bathysa nicholsonii. A and B - Fifth stage, outer cell wall. A - Uranyl acetate/lead citrate contrast. Note the disorganization of the cuticular membrane, especially the arborescent layer. B - Potassium iodine stain, revealing heterogeneous stain on cuticular extract. C and D - Sixth stage, outer cell wall, uranyl acetate/lead citrate contrast. Disorganization probably followed by arborescent layer degradation. Pol- outer cell wall polysaccharide layer. Bars: A - $0.25 \mu \mathrm{m}$. B, C, D - $0.4 \mu \mathrm{m}$.

hydrophilic channels was proposed. Paiva (2016) suggests that the lipid substances that are to diffuse through the cell wall are accumulated in the subcuticular space, causing increasing pressure, which, in many cases, can rupture the cuticle and allow the externalization of the secretion. The most commonly described mechanism for the release of secretion in colleters is through secretion accumulation in the subcuticular space. However, the pressure exerted by the accumulation of secretion itself cannot be enough to rupture the cuticle, as seen in species of Simira (Rubiaceae)
(Klein et al. 2004), B. nicholsonii (Rubiaceae) (Miguel et al. 2006), P. nuda (Rubiaceae) (Miguel et al. 2009), Copaifera langsdorffii (Fabaceae, Caesalpinioideae) (Paiva 2009), B. stipulata and B. gymnocarpa (Rubiaceae) (Miguel et al. 2010). On the other hand, in some cases a rupture may occur, as has been observed in Hymenaea stigonocarpa (Fabaceae: Caesalpinioideae) (Paiva \& Machado 2006), Alstonia scholaris (Apocynaceae) (Thomas \& Dave 1990) and Tocoyena bullata (Rubiaceae) (Miguel et al. 2016).

The mechanism of secretion liberation exhibited by 


\section{Cut. Prop}
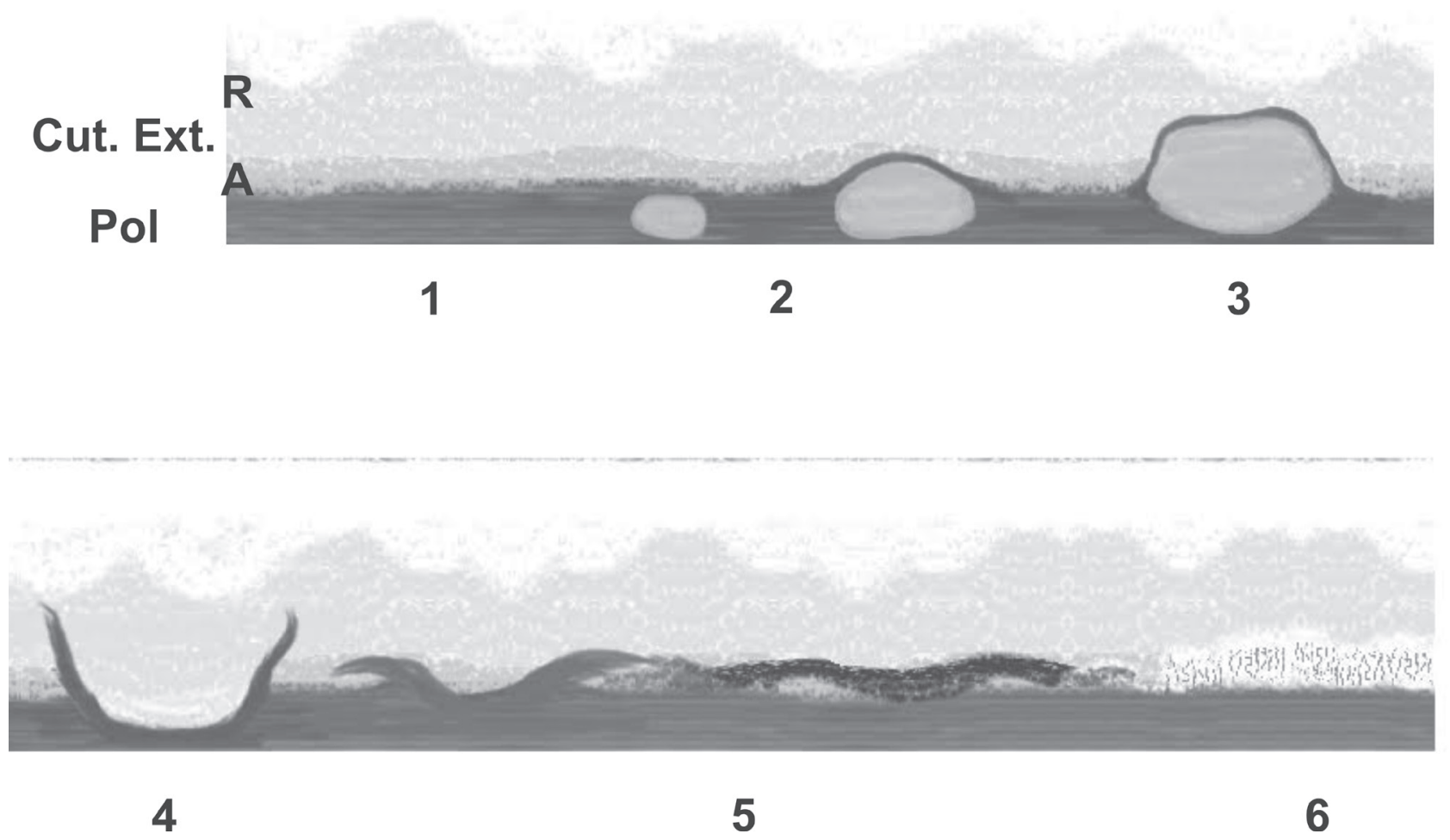

Figure 4. Dynamic model elucidating the different phases of secretion passage through the outer cell wall of colleters of Bathysa nicholsonii. One to six represents the different ultrastructural structures of the outer cell wall related to secretion passage: 1- Outer cell wall divided into polysaccharide rich layer (Pol), cuticular extract (Cut Ext), subdivided into reticulated (R) and arborescent (A) layers, and cuticle proper (Cut Prop); 2- Beginning of the development of the secretion accumulation site (SAS); 3- Development of the secretion accumulation site (SAS), occupying the polysaccharide rich layer and reticulate layer of cuticular membrane; 4- Secretion accumulation site disrupting; 5- Reorganization of cuticular membrane; 6- Drastic reorganization and/or degradation of the cuticular membrane. Note the cuticle proper remains intact throughout the entire processes.

B. nicholsonii colleters does not fit any of the previously proposed models of secretion because a SAS in a layer rich in polysaccharides was initially observed in these colleters. The cytochemical assay with osmium/imidazole and potassium iodide verified the presence of lipids in the lumen of these structures. Tullii et al. (2013) revealed the presence of lipids in the secretion of colleters of Alseis pickelii (Rubiaceae).

The amphipathic character of lipid compounds is an important factor to be considered, and may explain the formation of SAS in the polysaccharide-rich layer. Since the polysaccharide rich layer is hydrophilic, lipids are organized so that their polar region is exposed, with the apolar region facing the interior of the SAS. This arrangement makes the passage of secretions through the hydrophilic portion of the outer cell wall easier. Kim \& Mahlberg (2000) showed that the secretion passage through the outer cell wall of trichomes of Humulus lupulus (Cannabaceae) occurred through structures similar to the SAS found in B. nicholsonii; however, the authors described it as a secretory cavity.

In the third stage, the increase in size of SAS suggests the continuous flow of secretion at these sites. Paiva (2016) demonstrated that the passage of secretion from the cell wall occurs as a result of pressure from the cytoplasm that puts pressure on the substances accumulated in the periplasmic space, pushing it against the cell wall, thus forcing its passage. Although Paiva (2016) did not show the interaction of secretion with the different layers of the cell wall, this mechanism may explain the continuous flow of the secretion in SAS.

The SAS is disorganized as it crosses the polysacchariderich layer and reaches the cuticular membrane. The disorganization of this structure may be related to the hydrophobic characteristic of the cuticular membrane and lipid constitution of SAS. As soon as SAS reaches the cuticular membrane it is no long necessary for the secretion to aggregate to form SAS, since it is inserted in hydrophobic environments, which allows lipids to scatter easily through the outer cell wall until outsourced. Alberts et al. (2010) reported that lipids can diffuse rapidly in hydrophobic medium without taking specific conformations to facilitate passage. The reorganization of the cuticular membrane observed in later stages is a strong indication that the 
outer cell wall changes to facilitate the passage of secretion. The modifications observed in the outer cell wall may be related to the formation of environments that allow the free movement of the secretion (Kunst \& Samuels 2003). Since it is very difficult to determine the exact moment when secretion begins, we consider it to occur when there are changes to the cell walls of the secretory colleters. Due to having collected plants from the field and the nature of the studied secretory structure, it was not possible to determine if this process occurs more than once at the same place.

Externalization of the secretion possessed by $B$. nicholsonii did not involve cuticular rupture. In this sense, we can suggest that the release of secretion occurs by diffusion through the cuticle, as also reported by Veys et al. (2002). Permeability of the cuticle and epicuticular wax compounds was demonstrated by Kirsch et al. (1997), who also showed that the passage of these compounds through the cuticle occurs following the flow of cuticular water vapor. Based on Kirsch et al. (1997), and on features of lipid secretion, we suggest that the passage and liberation of secretion through the outer cell wall of colleters of B. nicholsonii occur through similar mechanisms.

\section{Conclusion}

The outer cell wall of the colleters of B. nicholsonii exhibited reorganization during the secretory process, suggesting a structural change during the passage of secretion at secretion accumulation sites. The results presented here demonstrate that the passage of the secretion through the outer cell wall is a dynamic mechanism, where the components of secretion tend to assume different conformations to pass through the different layers of the outer cell wall. In addition, the results show that the cell wall is a dynamic structure whose organization changes to facilitate the movement of secretion.

The externalization of the secretion present in the colleters of $B$. nicholsonii is unique. Thus, it was possible to develop a model that demonstrates how the passage of substances of secretion through the different layers of the outer cell wall to the external environment occurs.

\section{Acknowledgements}

The authors are indebted to Conselho Nacional de Desenvolvimento Científico e Tecnológico (CNPq), Fundação de Amparo a Pesquisa do Rio de Janeiro (FAPERJ), and Coordenação de Aperfeiçoando de Pessoal de Nível Superior (CAPES) for their financial support. We thank IBAMA for the plant-collecting license. This study was part of the $\mathrm{PhD}$ thesis of the first author, presented to the Programa de Pós-Graduação em Biociências e Biotecnologia - UENF. E.C. Miguel would like to thank the Central Analítica-UFC/ CT-INFRA/MCTI-SISNANO/Pró-Equipamentos CAPES.

\section{References}

Alberts J, Lewis R, Roberts W. 2010. Biologia molecular da célula. 5th. edn. Porto Alegre, Artmed.

Angermuller S, Fahimi HD. 1982. Imidazole-buffered osmium tetroxide: an excellent stain for visualization of lipids in transmission electron microscopy. The Histochemical Journal 14: 823-835.

Arpenter RAJC, Ordan GRJJ, Eigh ANL, Rodribb TIJB. 2007. Giant cuticular pores in Eidothea zoexylocarya (Proteaceae) leaves. American Journal of Botany 94: 1282-1288.

Ascensão L, Pais MS. 1998. The leaf capitate trichomes of Leonotis leonurus: histochemistry, ultrastructure and secretion. Annals of Botany 81: 263-271.

Cosgrove DJ. 2005. Growth of the plant cell wall. Nature Reviews Molecular Cell Biology 6: 850-61.

Da Cunha M, Vieira RC. 1993. Anatomia foliar de Psychotria velloziana Benth. (Rubiaceae). Rodriguesia 49: 39-50.

Dickison WC. 2000. Integrative plant anatomy. 1st. edn. San Diego, Academic Press.

Domínguez E, Cuartero J, Heredia A. 2011. An overview on plant cuticle biomechanics. Plant Science 181: 77-84.

Fahn A. 1979. Secretory tissues in plants. San Diego, Academic Press.

Fernández V, Guzmán-Delgado P, Graça J, Santos S, Gil L. 2016. Cuticle structure in relation to chemical composition: re-assessing the prevailing model. Frontiers in Plant Science 7: 427.

Fundação SOS Mata Atlântica, Instituto Nacional de Pesquisas Espaciais. 2002. Atlas dos remanescentes florestais da Mata Atlântica: período de 1995-2000. São Paulo, ArcPlan.

Gonzalez AM, Tarragó JR. 2009. Anatomical structure and secretion compounds of colleters in nine Ilex species (Aquifoliaceae) from southern South America. Botanical Journal of the Linnean Society 160: 197-210.

Guo Y, Wang D. 2016. Studies on plant cuticles from the Lower-Middle Devonian of China. Review of Palaeobotany and Palynology 227: 42-51.

Guzmán P, Fernández V, García ML, Khayet M, Fernández A, Gil L. 2014 Localization of polysaccharides in isolated and intact cuticles of eucalypt, poplar and pear leaves by enzyme-gold labelling. Plant Physiology and Biochemistry 76: 1-6.

Heredia A. 2003. Biophysical and biochemical characteristics of cutin, a plant barrier biopolymer. Biochimica et Biophysica Acta - General Subjects 1620: 1-7.

Kim ES, Mahlberg PG. 1997. Immunochemical localization of tetrahydrocannabinol (THC) in cryofixed glandular trichomes of Cannabis (Cannabaceae). American Journal of Botany 84: 336-342.

Kim ES, Mahlberg PG. 2000. Early development of the secretory cavity of peltate glands in Humulus lupulus L. (Cannabaceae). Molecules and Cells 10: 487-92.

Kirsch T, Kaffarnik F, Riederer M, Schreiber L. 1997. Cuticular permeability of the three tree species Prunus laurocerasus L., Ginkgo biloba L. and Juglans regia L.: comparative investigation of the transport properties of intact leaves, isolated cuticles and reconstituted cuticular waxes. Journal of Experimental Botany 48: 1035-1045.

Klein DE, Moreira GV, Silva-Neto SJ, Da Cunha M. 2004. The structure of colleters in several species of Simira (Rubiaceae). Annals of Botany 94: 733-40.

Kunst L, Samuels AL. 2003. Biosynthesis and secretion of plant cuticular wax. Progress in Lipid Research 42: 51-80.

Locke M, Huie P. 1983. The mystery of the unstained Golgi complex cisternae. Journal of Histochemistry \& Cytochemistry 31: 1019-1032.

Mahlberg PG, Kim ES. 1992. Secretory vesicle formation is glandular trichomes of Cannabis sativa (Cannabaceae). American Journal of Botany 79: 166-173.

Martins FM, Kinoshita LS, Castro MM. 2010. Coléteres foliares e calicinais de Temnadenia violacea. Revista Brasileira de Botânica 33: 489-500.

Martins FM, Lima JF, Mascarenhas AAS, Macedo TP. 2012. Secretory structures of Ipomoea asarifolia: anatomy and histochemistry. Revista Brasileira de Farmacognosia 22: 13-20. 


\section{Outer cell wall structure and the secretion mechanism of colleters of Bathysa nicholsonii K. Schum. (Rubiaceae)}

Miguel EC, Da Cunha M, Miguel TBAR, Barros CF. 2016. Ontogenesis secretion and senescence of Tocoyena bullata (Vell.) Mart. (Rubiaceae) colleters. Plant Biology 18: 851-858.

Miguel EC, Gomes VM, De Oliveira MAD, Da Cunha M. 2006. Colleters in Bathysa nicholsonii K. Schum. (Rubiaceae): Ultrastructure, secretion protein composition, and antifungal activity. Plant Biology 8: 715-722.

Miguel EC, Klein DE, Oliveira MAD, Da Cunha M. 2010. Ultrastructure of secretory and senescence phase in colleters of Bathysa gymnocarpa and B. stipulata (Rubiaceae). Revista Brasileira de Botânica 33: 425-436.

Miguel EC, Moraes DG, Da Cunha M. 2009. Stipular colleters in Psychotria nuda (Cham . \& Schltdl.) Wawra (Rubiaceae): micromorphology, anatomy and crystals microanalysis. Acta Botanica Brasilica 23:10341039.

Miller RH. 1985. The prevalence of pores and canals in leaf cuticular membranes. Supplemental Studies. Annals of Botany 57: 419-434.

Paiva EAS. 2009. Occurrence, structure and functional aspects of the colleters of Copaifera langsdorffii Desf. (Fabaceae, Caesalpinioideae). Comptes Rendus Biologies 32: 1078-1084.

Paiva EAS. 2016. How do secretory products cross the plant cell wall to be released? A new hypothesis involving cyclic mechanical actions of the protoplast. Annals of Botany 117: 533-540.

Paiva EAS, Machado SR. 2006. Ontogenesis, structure and ultrastructure of Hymenaea stigonocarpa (Fabaceae: Caesalpinioideae) colleters. Revista de Biologia Tropical 54: 943-950.

Pinheiro SKP, Sousa FX, Medeiros PRL, Miguel TBAR, Miguel EC. 2015. Environmental scanning electron microscopy (ESEM) of Morinda citrifolia L. (Rubiaceae) colleters. Acta Biomédica Brasiliensia 6:129140.

Pollard M, Beisson F, Li Y, Ohlrogge JB. 2008. Building lipid barriers: biosynthesis of cutin and suberin. Trends in Plant Science 13: 236-46.

Possobom CCF, Machado SR. 2005. Subcuticular space development in elaiophores of the Byrsonima intermedia (Malpigiaceae). Brazilian Journal of Morphological Sciences 1: 263-265.

Renobales G, Diego E, Urcelay B, López-Quintana A. 2001. Secretory hairs in Gentiana and allied genera (Gentianaceae, subtribe Gentianinae) from the Iberian Peninsula. Botanical Journal of the Linnean Society 136: 119-129.

Reynolds ES. 1963. The use of lead citrate at high $\mathrm{pH}$ as an electron-opaque staining in electron microscopy. Journal of Cell Biology 17: 208-212.

Riederer M, Schreiber L. 2001. Protecting against water loss: analysis of the barrier properties of plant cuticles. Journal of Experimental Botany 52: 2023-32.

Schönherr J. 2006. Characterization of aqueous pores in plant cuticles and permeation of ionic solutes. Journal of Experimental Botany 57: 2471-2491.

Stpiczynska M. 2003. Nectar resorption in the spur of Platanthera chlorantha Custer (Rchb.) Orchidaceae - Structural and microautoradiographic study. Plant Systematics and Evolution 238: 119-126.

Tenberge KB. 1992. Ultrastructure and development of the outer cell wall of spruce (Picea abies) needles. Canadian Journal of Botany 70: 1467-1487.

Thomas V. 1991. Structural, functional and phylogenetic aspects of the colleter. Annals of Botany 68: 287-305.

Thomas V, Dave Y. 1990. Mode of secretion in the colleters of Alstonia scholaris (Apocynaceae). Phyton 30: 209-212.

Thomson WW, Berry WL, Liu LL. 1969. Localization and secretion of salt by the salt glands of Tamarix aphylla. Proceedings of the National Academy of Sciences of the United States of America 63: 310-317.

Tullii CF, Miguel EC, Lima NB, Fernandes KVS, Gomes VM, Da Cunha M. 2013. Characterization of stipular colleters of Alseis pickelii Pilger et Shmale (Rubiaceae) on line first. Botany 91: 403-413.

Veys P, Lejeune A, Hove CV. 2002. The pore of the leaf cavity of Azolla species : teat cell differentiation and cell wall projections. Protoplasma 219: 31-42.

Vitarelli NC, Santos M. 2009. Anatomia de estípulas e coléteres de Psychotria carthagenensis Jacq . (Rubiaceae). Acta Botanica Brasilica 23: 923-928.

Wilkinson HP. 2007. Leaf teeth in certain Salicaceae and Flacourtiaceae. Botanical Journal of the Linnean Society 155: 241-256. 